related rather to changes in the efficiency of the utilization of chemical energy and its conversion to mechanical energy than to changes in the actual amount of the chemical energy used per beat ${ }^{5}$. This conception does not seem inconsistent with our interpretation of present results. Further research is needed, however, to elucidate the underlying processes.

The fact that the activation, besides triggering the contractile mechanism, modifies at the same time the rate of contractility restitution, and with it the strength of contraction according to the length of the preceding interval, may be of definite physiological significance in a muscle adapted to rhythmical activity. It leads to the idea of self-regulation in the heart muscle, of an efficacious mechanism - and perhaps the only possible one-allowing for a gradation of mechanical response in rhythmical activity.

V. Kruta

P. BRAVENÝ

Department of Physiology,

Faculty of Medicine,

University of Brno,

Czechoslovalkia.

- Siebens, A. A., Hoffman, B. F., Cranefield, P. F., and Broocks, C. McC., Amer. J. Physiol., 197, 971 (1959).

2 Bravený, P., and Kruta, V., Arch. Intern. Physiol., 66, 633 (1958).

${ }^{3}$ Kruta, V., and Bravený, P., Arch. Intern. Physiol., 69, 645 (1961).

4 Blinks, J. R., and Koch-Weser, J., J. Pharm, and Exp. Ther., 134, 373 (1961).

s Furchgot, R. F., and Lee, K. S., Circulation, 24, 416 (1961).

\section{Effect of Estradiol on Spinal Cord Convulsions in Developing Rats}

SPINAL cord convulsions can be elicited by direct spinal cord stimulation in 1-day-old rats'. In contrast, the tonicclonic seizure pattern of adult rats produced by electroshock stimulation of the brain $^{2}$ usually does not appear until the 2lst day of age. Thus, the spinal cord matures more rapidly, functionally, than do higher centres of the nervous system.

Previous investigations in this laboratory have demonstrated that oestradiol in adult rats increases brain excitability, as measured by a decrease in electroshock seizure threshold and by facilitation of the tonic phase of the maximal electroshock seizure ${ }^{3}$. In view of the part that spinal reflex systems play in determining the seizure pattern ${ }^{4}$, the question arises whether or not oestradiol exerts a significant action on these systems.

In a preliminary investigation, Heim and Timiras ${ }^{5}$ have found that in rats treated with cestradiol from the 8th to the 11th days after birth, the time of appearance of the ability to exhibit a tonic-clonic seizure was hastened by two days over that of the controls. These authors have suggested that œestradiol induces precocious maturation in the brain. However, the role of spinal reflex systems should be considered.

The following experiments were performed to examine the effect of œstradiol on spinal cord convulsion patterns in rats during maturation.

CEstradiol dipropionate in a dose of $1 \mathrm{mg} / \mathrm{kg}$ (in $0.01 \mathrm{ml}$. 'Mazola' solution/g body-weight) was administered to rats daily from the 8 th to the 11th days after birth. Control animals received $0.01 \mathrm{ml} . / \mathrm{g}$ body-weight of 'Mazola' for the same period. Spinal cord convulsions were elicited in both control and œstradiol-treated rats on the 12th and 2 lst days of age. The technique for direct spinal cord stimulation was that deseribed by Esplin and Freston ${ }^{4}$ and modified by Vernadakis ${ }^{1}$. The animals were decapitated at the cervical region and the stimulating electrode (cathode) was inserted 4-5 mm into the cord. The anode was attached to exposed tissue of the neck. Square-wave stimuli $1 \mathrm{msec}$ in duration and of 100 pulses/sec frequency were delivered by a Grass stimulator at a stimulus in- tensity of $30 \mathrm{~V}$. Spinal cord stimulation of 10 -sec duration was applied 15 sec after decapitation. The end points of hind-limb flexion and extension were measured by an electronic timer. The duration of flexion is utilized as a standard index of seizure intensity; the shorter the duration of flexion the more severe is the convulsion ${ }^{6}$.

The duration of flexion in control and ostradiol-treated rats 12 and 21 days of age are presented in Table 1. In both ages the duration of flexion in the ostradiol-treated animals is significantly decreased; the decrease in 12-dayold oestradiol-treated rats is more marked than that in the 21-day-old. These results illustrate that œestradiol administration increases the reflex excitability of the spinal cord and that this increase in excitability persisted during the experimental period; they are in agreement with previous studies ${ }^{2,5}$ showing that ostradiol has long-lasting effects on developing rats.

Table 1. EFfect of CEstradiol* on Spinal CoRd Convulsions in Rats

\begin{tabular}{|c|c|c|}
\hline $\begin{array}{l}\text { Age: } \\
\text { days after birth }\end{array}$ & $\begin{array}{c}\text { Duration of hind } \\
\text { Control }\end{array}$ & $\begin{array}{l}\text { mb flexion (sec) } \\
\text { OEstradiol }\end{array}$ \\
\hline 12 & $1.58 \pm 0.18 t$ & $0.99 \pm 0.04$ \\
\hline 21 & $1.32 \pm 0.13$ & $\begin{array}{c}0.95 \pm 0.004 \\
(0.05-0.02)\end{array}$ \\
\hline
\end{tabular}

* CEstradiol was injected subcutaneously from the 8 th to the 11th days after birth. 8-16 rats were used in each age period.

$\dagger \pm S . E$.

\$ Number in parentheses is $P$ value for comparison to control.

It has been suggested in previous investigations ${ }^{5}$ that cestradiol, given at a critical period of development, enhances the appearance of the full tonic hind-limb extensor seizure by inducing precocious maturation of the higher centres of the nervous system. In the present investigation ostradiol given at a critical period of the development of higher centres increases the level of activity of spinal reflex system. Thus, it may be suggested that the enhanced appearance of a full tonic--clonic seizure in oestradiol-treated developing rats can be attributed in part to an increased level of spinal reflex excitability.

This work was supported by U.S. Public Health Service grant $R G-9267$.

\section{Antonia Vernadakis} Paola S. Trmiras

Department of Physiology,

University of California, Berkeley.

1 Vernadakis, A., Science, 137, 532 (1962).

'Millichap, J. G., Proe. Soc. Exp. Biol. and Med., 96, 125 (1957). Vernadakis, A., Ph.D. thesis, University of Utah (1960).' Heim, L. M.. and Timiras, P. S., Fed. Proce., 21, 338 (1962).

${ }^{3}$ Woolley, D. E., and Timiras, P. S., Endocrinol., 70, 196 (1962). Woolley, D. E., and Timiras, P. S., Endocrinol., 71, 609 (1962). ‘ Esplin, D. W., and Laffan, R. J., Arch. Intern. Pharmacodyn., 113, 189 Therap., 130, 68 (1960).

'Heim, L. M., and Timiras, P. S., Abstract published in Excerpta Mediru, Intern. Cong. Ser., No. 51, 281 (1962). ${ }^{6}$ Toman, J. E. P., Swinyard, F. A., and Goodman. L. S., J. Neurophysiol.,
9, 231 (1946).

\section{Permeability of Dermal Connective Tissue in Normal and Scorbutic Guinea Pigs}

RECENT work has shown that the permeability of capillary blood vessel walls does not seem to be affected by scurvy ${ }^{1}$ despite the presence of hæmorrhages. However. capillary resistance was shown to decrease $\theta^{2-6}$ and the corresponding capillary fragility increased ${ }^{6,7}$. No investigations of the influence of scurvy on the permeability of dermal and connective tissue have been made.

To examine the effect of scurvy on dermal and subcutaneous tissue, we used young guinea pigs weighing 250$400 \mathrm{~g}$, fed ad lib. on Wayne guinea pig diet containing 420 $\mathrm{mg}$ of vitamin $\mathrm{C}$ (added) per $100 \mathrm{~g}$ of diet. To induce scurvy, the guinea pigs were placed for 15-17 days on Wayne 'Lab Blox' (mice and rats), which contained practi- 